Tinjauan Literatur

\title{
PERAN ASPEK KLINIKOPATOLOGI, IMUNOFENOTIP, DAN ANALISIS KLONALITAS UNTUK MENEGAKKAN DIAGNOSIS MYCOSIS FUNGOIDES
}

\author{
Diah Prabawati Retnani ${ }^{\star 凶}$
}

\begin{abstract}
Abstrak
Mycosis fungoides (MF) adalah prototipe dari cutaneous T-cell lymphoma (CTCL) yang bersifat indolen, dengan evolusi klinis yang lambat berupa bercak, plak dan tumor. Diagnosis MF pada stadium dini merupakan tantangan yang cukup berat bagi ahli patologi karena spesimen kulit yang diperiksa sering tidak adekuat, tidak khas dan dapat menyerupai dermatitis kronis yang resisten terhadap terapi. Diagnosis MF yang akurat memerlukan korelasi klinikopatologi yang seksama karena setiap stadium MF memiliki diagnosis banding yang berbeda baik secara klinis maupun histopatologi. Pengambilan spesimen jaringan pada lesi awal melalui biopsi terbuka (biopsi plong maupun insisional) harus mempertimbangkan waktu dan lokasi yang tepat. Aspek karakteristik klinikopatologi, imunofenotip dan pemeriksaan analisis klonalitas diharapkan dapat membantu diagnosis dengan mengurangi kemungkinan terjadinya overdiagnosis maupun underdiagnosis.
\end{abstract}

Kata kunci : dermatitis kronis, mycosis fungoides stadium dini.

\section{THE ROLE OF CLINICOPATHOLOGICAL, IMMUNOPHENOTYPING, AND CLONALITY ANALYSIS TO ESTABLISHING THE DIAGNOSIS OF MYCOSIS FUNGOIDES}

\begin{abstract}
Mycosis fungoides (MF) is a prototype of cutaneous T-cell lymphoma (CTCL) with indolent behavior and slowly clinical evolution such patch, plaque, and tumor. Diagnosis of MF in early stage is an extremely difficult challenge for pathological experts because skin specimen from a punch or incisional biopsy is almost always inadequate to diagnose and has nonspecific features like therapy-resistant chronic dermatitis. An accurate MF diagnosis needs careful clinicopathological correlation because every stage has a clinical and histopathological differential diagnosis. Taking a tissue sampling in early MF from open biopsy (punch or incisional biopsy) should consider the best site and timing. Clinicopathological characteristics, immunophenotyping and clonality analysis examination can help to make an accurate diagnosis and eliminate the possibility of overdiagnosis or underdiagnosis.
\end{abstract}

Keywords: chronic dermatitis, early stage mycosis fungoides.

*Departemen Patologi Anatomi, Fakultas Kedokteran, Universitas Brawijaya

E-mail: prabawatijatmiko@yahoo.com 


\section{Pendahuluan}

Cutaneous T-cell lymphoma (CTCL) adalah limfoma sel $T$ yang terjadi pada kulit dan dapat bersifat indolen maupun agresif. 1-3 Mycosis fungoides (MF) adalah prototipe dari CTCL yang bersifat indolen, dengan evolusi klinis yang lambat berupa berupa bercak, plak, dan tumor. ${ }^{3}$ Stadium dini MF dapat berjalan bertahun-tahun, dengan gambaran klasik berupa bercak kemerahan dan plak tipis, dapat menyerupai dermatosis kronik akibat radang, psoriasis maupun infeksi jamur. Mycosis fungoides secara histopatologi memiliki kemiripan dengan sejumlah lesi likenoid maupun limfoproliferatif yang lain. Pada stadium lanjut, terjadi perubahan gambaran klinis berupa plak yang tebal dan tumor, serta dapat berdiseminasi ke dalam kelenjar getah bening maupun organ internal. Sekitar $15-20 \%$ dari kasus MF yang berjalan indolen akan berkembang menjadi stadium yang lanjut. ${ }^{4}$

Diagnosis MF yang akurat memerlukan korelasi klinikopatologi yang seksama karena setiap stadium MF memiliki diagnosis banding yang berbeda baik secara klinis maupun histopatologi. Pengambilan sampel jaringan pada lesi awal melalui biopsi plong atau insisional dengan mempertimbangkan waktu dan lokasi yang tepat Fine needle aspiration biopsy (FNAB) hanya dapat dilakukan pada lesi yang berupa massa seperti MF pada stadium tumor. Selain memiliki teknik yang mudah, cepat dengan komplikasi yang minimal, FNAB memiliki akurasi cukup tinggi untuk beberapa jenis tumor seperti pada tumor musculoskeletal dan juga pada tumor kulit.5,6 Pemeriksaan imunofenotip dan biologi molekuler yang memperlihatkan klonalitas limfosit T dibutuhkan ketika gambaran klinis sesuai dengan MF, namun fitur histopatologi klasik dari MF tidak ditemukan. ${ }^{4}$

Studi epidemiologik yang diambil dari data Surveillance, Epidemiology and End
Result (SEER) menyatakan bahwa kasus CTCL di sejumlah negara di dunia termasuk Amerika mengalami peningkatan. 4,7 Hal ini menunjukkan bahwa deteksi dan diagnosis MF stadium dini kian akurat. Insiden CTCL 10 tahun terakhir adalah 10 kasus per seribu individu setiap tahunnya. Data di Laboratorium Patologi Anatomi RSUD Dr. Saiful Anwar Malang pada tahun 2014-2018 menunjukkan jumlah kasus keganasan hematolimfoid pada kulit sekitar 10 kasus, tiga di antaranya adalah kasus MF. Meskipun angka kejadian MF masih tergolong rendah dibandingkan dengan keganasan epitelial kulit, namun penegakan diagnosisnya cukup rumit karena membutuhkan kajian yang seksama dari berbagai aspek pemeriksaan. Diagnosis yang akurat berpengaruh pada terapi dan prognosis dari penderita.

Artikel ini disusun dengan tujuan untuk mengetahui kriteria diagnosis MF berdasarkan karakteristik klinikopatologi, imunofenotip dan pemeriksaan analisis klonalitas, sehingga dapat mengurangi kemungkinan terjadinya overdiagnosis maupun underdiagnosis.

\section{Definisi}

Mycosis fungoides (MF) adalah limfoma primer dari sel T pada kulit (CTCL) dengan gambaran epidermotropisme yang memiliki karakteristik infiltrat limfosit $\mathrm{T}$ berukuran kecil hingga sedang berinti cerebriform. Terminologi MF hanya digunakan pada CTCL klasik dengan evolusi klinis berupa bercak, plak dan tumor serta beberapa varian yang menunjukkan evolusi klinis tersebut. 3,7 Mycosis fungoides merupakan kelainan klonal limfosit T-helper memori dimana terjadi defisiensi imun dari tubuh inang. Mycosis fungoides dapat bertahan pada kulit selama bertahun-tahun tanpa penyebaran meskipun kurang dari $20 \%$ kasus dapat berkembang menjadi lebih progresif.2,4 


\section{Epidemiologi}

Angka kejadian MF sekitar 5-6 kasus/1000 penduduk/tahun dengan sebaran wilayah geografis di dunia yang bervariasi, terutama pada ras kulit hitam. ${ }^{3}$ Predileksi MF terbanyak di area kulit yang terlindung sinar matahari. 2,8 Jumlah kasus MF pada laki-laki $2 x$ lebih tinggi daripada wanita dengan rerata usia 55 tahun. ${ }^{2}$ Di Amerika, jumlah kasus yang terdiagnosis MF tercatat sekitar 0,360,46 kasus $/ 10^{5}$ populasi tiap tahunnya, seribu di antaranya adalah kasus baru. ${ }^{9}$ Progresifitas MF tergolong rendah, berevolusi dari stadium bercak, menjadi plak dan tumor. ${ }^{7}$ Eritroderma dapat terjadi meskipun jarang. Angka harapan hidup MF dalam 5 tahun (5 ysr) sekitar $90 \%, 7,10,11$

\section{Etiopatogenesis}

Sejumlah studi menyatakan bahwa etiologi klonalitas limfosit $T$ berasal dari berbagai agen penyebab, di antaranya antigen virus (HTLV-1), bakteri, superantigen, autoantigen, sel efektor $\mathrm{CLA}+$, kemokin, profil sitokin Th1 (IL-7, IL17, IL-18, IL-21, dan IL22) dan Th2 (IL-4 dan IL-5). ${ }^{10}$ Salah satu teori menyatakan bahwa klonalitas limfosit $T$ pada MF berasal dari limfosit T memori CD4+ CD45RO+ yang berpotensi migrasi ke kulit dan berhubungan dengan infeksi human $T$ lymphocyte virus-1 (HTLV1).7,12 Virus HTLV1 memiliki gen tax -yang memproduksi protein Tax- sehingga dapat mempengaruhi transformasi genom limfosit T normal. Protein Tax juga menyebabkan replikasi virus RNA melalui stimulasi transkripsi virus RNA, peningkatan survival dan pertumbuhan limfosit $T$ yang telah terinfeksi, meningkatkan genomic instability melalui gangguan terhadap fungsi perbaikan DNA serta menghambat checkpoint pada siklus sel akibat kerusakan DNA. ${ }^{13}$ Meskipun demikian, limfosit $T$ yang telah mengalami transformasi neoplastik tersebut tidak memiliki kapasitas proliferasi secara otonom sehingga progresifitasnya tergolong rendah. Proliferasi klonal limfosit $T$ dapat pula dipacu oleh hilangnya ketahanan imun, perubahan lingkungan mikro serta hadirnya limfosit $T$ CD8+ sitotoksik poliklonal dan sel-sel dendritik.

Teori lain menyatakan bahwa sebelum dan pada awal stadium bercak, dermis berisi limfosit T normal dan epidermis mengandung sel-sel langerhan, pembuluh darah mengandung lgE, monosit dan sel dendritik. Pada keadaan inflamasi kronis dengan berbagai sebab, lingkungan mikro yang mendukung akan menyebabkan migrasi limfosit $T$ neoplastik ke dalam dermis yang diatur oleh CLA, kemokin beserta reseptornya (CCR4, CCR10, CCL17, CCL27) serta berbagai sitokin (IL-15, IL16, IL17, IL21, IL-22). Limfosit $T$ efektor pada kutan dapat mengekspresikan CLA untuk berinteraksi dengan reseptor E-selektin pada venul post kapilar dermis. CCL17 dan CCL22 akan terekspresi kuat pada lesi MF. Pada stadium bercak dan plak, CXCR3 dan CLA akan terekspresi kuat pada limfosit T CD4+ neoplastik, sehingga menyebabkan limfosit $T$ $\mathrm{CD} 4+$ neoplastik tersebut mudah masuk ke dalam epidermis (epidermotropism). Pada stadium tumor keberadaan CXCR3 dan CLA akan menurun sehingga gambaran epidermotropisme maupun Pautriers microabcess tidak dapat ditemukan lagi pada pemeriksaan histopatologi. ${ }^{10}$

Lingkungan mikro yang mendukung terjadi MF tercermin pada faktor risiko yang dialami pasien dengan body mass index (BMI) $\geq 30 \mathrm{~kg} / \mathrm{m}^{2}$, perokok sigaret lebih dari 40 tahun, keadaan eksim yang terus menerus, riwayat keluarga dengan multiple myeloma, serta beberapa profesi seperti petani, tukang kayu, tukang cat. 10 


\section{Pengambilan Spesimen Biopsi}

Biopsi plong maupun insisi tidak menjamin diagnosis MF dapat ditegakkan secara mutlak, baik dengan serangkaian pemeriksaan imunofenotip maupun analisis klonalitas menggunakan TCR-gene rearrangement. Banyak faktor yang dapat mempengaruhi hasil pemeriksaan histopatologi, di antaranya pengambilan spesimen biopsi pada lesi dengan bentuk yang tidak khas meskipun secara teknis mudah dilakukan. Terapi topikal yang beragam dan berganti-ganti, radiasi sinar UV jangka panjang, pengambilan spesimen pada area yang sering digaruk maupun area yang terekspos sinar matahari juga mempengaruhi hasil pemeriksaan histopatologi. Penghentian terapi selama 2-3 minggu sebelum dilakukan biopsi ulang dapat memperjelas gambaran histopatologi. ${ }^{14}$

\section{Gambaran Klasik Gejala Klinis dan Histopatologik Mycosis Fungoides}

Mycosis fungoides memiliki onset yang lambat dan menahun sehingga sulit dibedakan dengan lesi kulit nonneoplastik pada stadium dini. Durasi rata-rata dari penampakan awal gejala kulit sampai tegak diagnosis MF sekitar 6 tahun. Stadium klinis pada MF terdiri dari stadium bercak, plak, dan tumor. ${ }^{7}$ Mycosis fungoides memiliki varian klinis yang lebih jarang berupa eritrodermi, bula, hipopigmentasi, verukosa, pustular, palmoplantar dan acanthosis nigrican-like namun tetap memiliki perjalanan penyakit seperti MF klasik. ${ }^{9}$

\section{A. Mycosis Fungoides Stadium Bercak}

\section{Gejala Klinis Mycosis Fungoides Stadium Bercak}

Pada awal onset terjadi bentuk bercak (lesi datar bersisik), irreguler, asimetris, berwarna pink, ungu tua hingga kemerahan, dengan batas jelas, ukuran bervariasi, tunggal maupun multipel bersisik dengan ukuran dan jumlah bervariasi dari 2 sampai $15 \mathrm{~cm}$, bentuk oval kadang digitate/ finger shape (menjari) (Gambar 1A). Lesi ini terjadi umumnya pada daerah yang tertutup sinar matahari, area intertriginosa dengan gambaran 'bathing trunk' seperti gluteus, abdomen, lipat paha serta di bawah lipatan payudara pada wanita. 7, 9,15

Pruritus merupakan gejala yang umum dan seringkali parah. Pada stadium ini diagnosis akan sulit ditegakkan. Keadaan semacam ini hilang timbul, dapat berlangsung hingga 10-20 tahun dan sering dianggap sebagai dermatitis kronis -seperti dermatitis kontak, atopia, psoriasis maupun eksimnamun resisten terhadap terapi. ${ }^{11,15}$

Sebagian dari pasien dapat menceritakan pola dan perjalanan lesi sebelumnya, namun sebagian lainnya hanya merasakan kulitnya berubah menjadi tipis dan keriput, ditandai dengan hipo dan hiperpigmentasi. Keadaan ini dikenal sebagai poikiloderma atrophicans vasculare.7,9

\section{Gambaran Histopatologik Mycosis Fungoides} Stadium Bercak

Istilah stadium dini MF dikenal pula dengan istilah clonal dermatitis, parapsoriasis, generalized idiopathic follicular mucinosis, $T$ cell dyscrasia. ${ }^{14}$ Stadium bercak memiliki gambaran histopatologi yang bervariasi dari epidermis yang terlihat normal hingga fitur yang patognomonis untuk MF. Cerroni dkk (2005) melakukan penelitian tentang gambaran histopatologi dari 745 spesimen biopsi yang diperoleh dari 427 pasien dengan MF stadium dini di Austria. Gambaran histopatologi yang dapat ditemukan pada MF stadium dini dapat dilihat pada Tabel 1.

Mycosis fungoides stadium dini memiliki gambaran terbanyak berupa fibrosis papilla dermis $(97 \%)$ diikuti adanya infiltrat limfosit fokal pada dermis $(66 \%)$. 


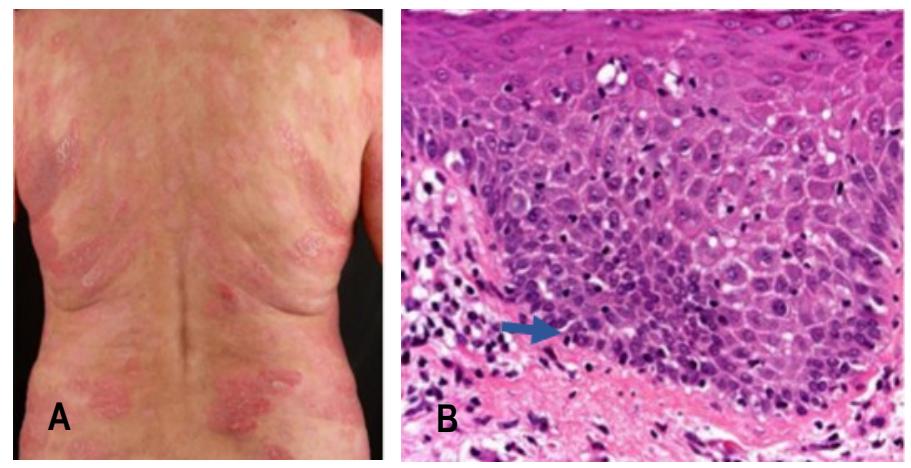

Gambar 1. Mycosis fungoides stadium bercak.

Keterangan: A. Lesi berupa bercak kemerahan, batas jelas, ukuran bervariasi pada punggung. B. Jajaran limfosit pada stratum basalis menyerupai string of pearls (tagging) (panah biru) (Pewarnaan HE, 100x). ${ }^{14}$

Tabel 1. Gambaran histopatologi mycosis fungoides stadium bercak. ${ }^{14}$

\begin{tabular}{lc}
\hline \multicolumn{1}{c}{ Gambaran Histopatologi } & Persentase Kejadian (\%) \\
\hline Epidermis normal & 48 \\
Hiperplasia psoriasiform & 35 \\
Hiperplasia ireguler & 4 \\
Epidermis flat dan atrofi & 13 \\
Spongiosis yang nyata & 4 \\
Keratinosit nekrosis & 23 \\
Perubahan pada dermoepidermal junction (interface dermatitis) & 61 \\
Epidermotropisme & 40 \\
Tidak ditemukan epidermotropisme & 4 \\
Limfosit atipik & 9 \\
Infiltrat limfosit pada dermis (patchy lichenoid) & 66 \\
Perubahan pada dermis (fibrosis/edema pada papilla dermis) & 97 \\
Purpura & 8 \\
Melanofag & 4 \\
\hline
\end{tabular}

Reaksi likenoid berupa infiltrat limfosit padat di perbatasan dermis-epidermis (interface dermatitis), terjadi pada $61 \%$ kasus. Gambaran epidermotropisme yaitu infiltrasi limfosit atipik dengan inti bulat ireguler, dikelilingi halo pada epidermis tanpa disertai spongiosis di sekitarnya juga sering ditemukan. 1,7 14,16

Diagnosis MF stadium dini memerlukan korelasi biopsi multipel dari beberapa lokasi dan pengulangan pengambilan biopsi di lain waktu. Mycosis fungoides stadium dini sering disertai sel eosinofil pada dermis dan epidermis dalam jumlah lebih banyak dibandingkan dermatitis kontak alergi atau atopi. $^{7}$

Keberadaan sel limfosit $T$ sering tersusun linier (pola lentiginosa) pada zona membran basal yang dikenal sebagai tagging atau string of pearls (Gambar 1B).2,9 Epidermotropisme biasanya tidak disertai spongiosis pada epidermis/folikel rambut, namun sekitar $30 \%$ kasus MF menunjukkan spongiosis fokal yang berada cukup jauh dari infiltrat sel limfosit T neoplastik. 
Tabel 2. Diagnosis banding histopatologi Mycosis fungoides stadium bercak. 1,7,11,17

\begin{tabular}{ll}
\hline Pola Reaksi Histopatologi & \multicolumn{1}{c}{$\begin{array}{c}\text { Penyakit yang Memberikan Gambaran Pola Histopatologi Serupa } \\
\text { dengan Mycosis Fungoides }\end{array}$} \\
\hline Pola Psoriasiform dan & \multicolumn{1}{c}{ Sifilis sekunder } \\
Likenoid & Purpura likenoid \\
& Liken striatus \\
& Liken sklerosus et atropikus \\
& Morfea \\
& Pitiriasis likenoides \\
& Reaksi obat \\
Pola Spongiotik, & Bulous pemfigoid fase urtikaria \\
Psoriasform dan Likenoid & Reaksi obat \\
& Dermatitis kontak alergik/ Dermatitis kontak likenoid \\
& Dermatitis kronik fotoalergik \\
Pola Atropik Likenoid & Mycosis fungoides stadium bercak atropik \\
& Liken planus atropik \\
& Purpura likenoid \\
& Melanoma regresi, penyakit Bowen, superficial basal cell carcinoma \\
& Lesi poikilodermatous dari dermatomiositis
\end{tabular}

Beberapa kasus menunjukkan gambaran epidermal atropi maupun hiperplasia psoriasiform dengan parakeratosis fokal dan hyperkeratosis. ${ }^{9}$ Papila dermis dapat mengalami fibrotik berat dengan atelektasis dan sebaran melanofag. Berkas kolagen pada papila dermis tersusun vertikal dan tidak teratur, biasanya terjadi akibat garukan. ${ }^{9}$ Pada Tabel 2 ditampilkan gambaran histopatologik yang dapat dijumpai pada lesi awal MF, sehingga mengaburkan fitur yang patognomonis jika tidak diamati dengan seksama.

\section{B. Mycosis Fungoides Stadium Plak}

\section{Gejala Klinis Mycosis Fungoides Stadium Plak}

Bercak dan plak dapat terlihat sebagai kondisi kulit dengan telangiektasis, atropi, hipopigmentasi dan/atau hiperpigmentasi yang disebut poikiloderma. Progresifitas dari bercak menjadi plak hingga tumor adalah variasi yang sulit diprediksi. Lesi plak berbatas jelas dan bersisik dengan indurasi yang bervariasi, berwarna merah kehitaman hingga keunguan gelap dan dapat mengalami remisi spontan atau bergabung membentuk konfigurasi tertentu (annular, semiannular, serpigi- nosa). Lesi dapat menyerupai dermatofitosis karena bagian sentral lesi dapat menyembuh dengan tepi yang aktif.

Mycosis fungoides yang meliputi $80 \%$ area permukaan tubuh dengan batas tidak jelas dan terdapat riwayat hilang timbulnya stadium bercak dan plak dikategorikan sebagai MF eritrodermi. Lesi plak maupun eritrodermi dapat berasal dari lesi bercak maupun de novo(15 Kulit pada MF eritrodermi terlihat lebih merah, terang dan difus, bersisik membentuk pulau-pulau terutama di daerah lipatan abdomen, antecubiti dan aksila (folded luggage sign).

Mycosis fungoides eritrodermi sering disertai gejala sistemik berupa demam, penurunan berat badan, malaise, insomia karena pruritus hebat hingga kehilangan keseimbangan suhu tubuh. Gejala yang lebih jarang berupa fisura, nyeri, sisik pada telapak tangan dan kaki, alopesia, distrofi kuku, edema pergelangan kaki dan kulit menjadi mengkilat. Diagnosis banding MF stadium eritrodermi secara klinis adalah Sezary syndrome, psoriasis vulgaris fase eritrodermi dan chronic spongiotic dermatitis. Pasien dengan MF eritrodermi dapat berkembang menjadi stadium tumor. ${ }^{15}$ 


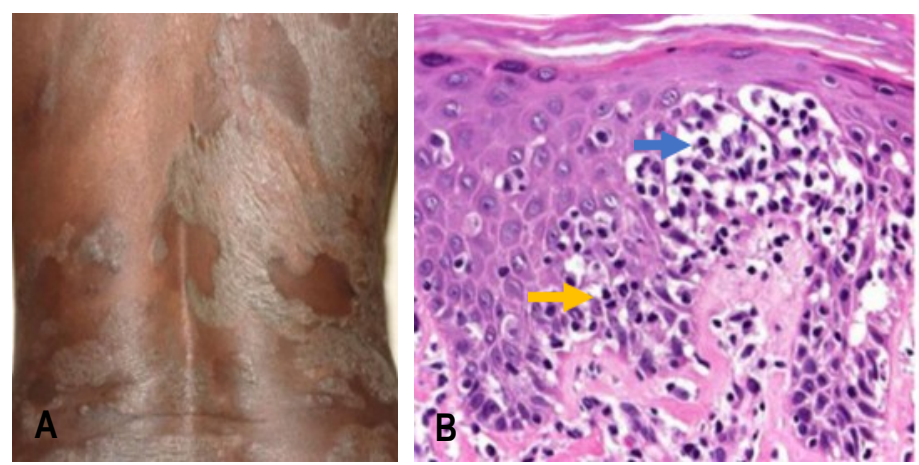

Gambar 2. Mycosis fungoides stadium plak.

Keterangan: A. Lesi berupa plak di punggung dengan variasi ukuran, berskuama tipis, menyatu dan membentuk kepulauan. B. Epidermotropisme limfosit T atipik (panah kuning) dan Pautrier's microabcess (panah biru) (Pewarnaan HE, 100x). ${ }^{14}$

Gambaran Histopatologik Mycosis Fungoides Stadium Plak

Lesi MF stadium plak dan eritrodermi dapat memiliki kesamaan gambaran histopatologik yaitu infiltrat limfosit $\mathrm{T}$ padat, berbentuk band-like pada dermis superfisial. Pada stadium plak lebih terlihat epidermotropisme yang nyata pada epidermis. Bentuk limfosit T neoplastik berinti bulat, serebriform dan hiperkonvolusi kadang berkelompok membentuk formasi intraepidermal Pautrier's microabcess tanpa pelebaran jarak antar keratinosit atau spongiosis.9,15 Pautrier's microabcess yang terdapat pada MF berbentuk bulat, berbeda dengan langerhans cells pustule pada chronic spongiotic dermatitis yang berbentuk vas dengan bagian atas terbuka pada lapisan spinosum. Langerhans cells pustule berisi komponen yang heterogen, yang terdapat sel Langerhans berinti pucat, vesikuler, reniform dan mengekspresikan CD1a atau Langerin. ${ }^{7}$ Mycosis fungoides maupun psoriasis vulgaris menunjukkan pola hiperplasia psoriasiform, namun fitur histopatologi dari psoriasis vulgaris tidak mengandung eosinofil seperti pada MF.

Menurut sistem klasifikasi World Health Organization-European Organization for Research and Treatment of Cancer (WHO/ EORTC), Sezary syndrome (SS) merupakan entitas tersendiri yang dapat bersifat agresif dengan prognosis yang buruk. Triad dari SS adalah eritrodermi, limfadenopati masif dan peningkatan kadar sel Sezary pada darah lebih dari $1000 \mathrm{sel} / \mu \mathrm{L} .^{2}$ Diagnosis banding MF stadium plak adalah lymphomatoid papulosis (LyP) tipe $B$ dan $D$, serta primary cutaneus CD8+ aggresive epidermotropic cytotoxic $T$ cell lymphoma disebabkan gambaran epidermotropisme yang dominan. ${ }^{3}$

\section{Mycosis Fungoides Stadium Tumor}

\section{Gejala Klinis Mycosis Fungoides Stadium Tumor}

Tumor merupakan stadium yang muncul pada sekitar 10\% kasus MF, berupa indurasi kemerahan, permukaan halus namun sering ulseratif disertai infeksi sekunder dan dapat menjadi penyebab morbiditas. Pada stadium ini, MF perlu dibedakan dengan diagnosis bandingnya yaitu pseudolimfoma dan limfoma jenis lain. $1,7,11$

\section{Gambaran Histopatologik Mycosis Fungoides} Stadium Tumor

Keadaan epidermotropisme pada stadium tumor biasanya telah menghilang. Hal ini diduga akibat hilangnya ekspresi beberapa integrin, khususnya aE $\beta 7$. Pada dermis terlihat pertumbuhan vertikal populasi sel dengan bentuk inti serebriformis, campuran dari imunoblas, limfoblas, dan sel pleoimorfik ukuran kecil hingga besar dengan inti hiperkromatik. 
Sekitar 25\% kasus MF stadium tumor dapat bertransformasi menjadi sel besar (large cell transformation).2,7 Mycosis fungoides dengan transformasi sel besar memiliki jumlah sel besar sebanyak $>25 \%$ dari seluruh populasi sel neoplastik yang mirip dengan sel limfoblas, dengan anak inti prominen dan banyak mitosis atipik. ${ }^{2}$ Transformasi sel besar pada MF memiliki gambaran histopatologi yang mirip dengan lymphomatoid papulosis (LyP) tipe A dan E, anaplastic large cell lymphoma (ALCL), Hodgkin lymphoma (HL) dan cutaneus adult T-cell leukemia/lymphoma (ATLL). ${ }^{3}$

\section{Varian Klinikopatologik Mycosis Fungoides}

Mycosis fungoides terdiri dari berbagai varian klinis dan histopatologik. Varian MF yang menurut WHO 2018 dan EORTC dianggap memiliki gambaran klinikopatologi dan prognosis berbeda diklasifikasikan dalam entitas varian MF, yaitu folliculotropic mycosis fungoides (FMF), pagetoid reticulosis (Woringer-Kolopp disease) (PR) dan granulomatous slack skin (GSS).3,9

\section{Folliculotropic Mycosis Fungoides (FMF)}

Folliculotropic mycosis fungoides (FMF) adalah varian dari MF dengan morfologi berupa infiltrat limfosit di sekitar folikel rambut (folikulotropik), pada epidermis di daerah kepala leher dengan patogenesis yang serupa dengan MF tipe klasik dan cenderung membentuk Pautrier's microabcess. Varian FMF memiliki prognosis yang lebih buruk dibanding MF klasik.

\section{Gejala Klinis FMF}

Folliculotropik mycosis fungoides lebih sering terjadi pada laki-laki dewasa dengan gejala klinis berupa kelompok papul folikuler, lesi akneiformis, plak indurasi dan tumor. Lesi berada di sekitar folikel rambut dengan tanda khas berupa plak pada alis yang bersamaan dengan alopesia. Lesi ini memberikan gejala pruritus yang sangat hebat, kadang dengan sekret musin dan sering didapatkan infeksi bakteri sekunder akibat garukan.

\section{Gambaran Histopatologik FMF}

Folikel rambut pada FMF terlihat intak dengan infiltrat limfosit perifolikuler dan intrafolikuler dengan atau tanpa musinosis folikuler. Pada beberapa potongan spesimen, dapat terlihat sekumpulan dari limfosit atipikal intrafolikular yang juga dikenal sebagai Pautrier's microabcsess. Diagnosis banding varian FMF adalah folikulitis karena seringkali tidak terlihat epidermotropisme yang prominen pada epidermis. ${ }^{2}$ Penanda FMF berupa debris keratin pada folikel rambut disertai sebukan eosinofil dan sel plasma yang cukup banyak.

\section{Pagetoid Reticulosis (PR)}

Pagetoid reticulosis (PR) dulu dianggap sebagai entitas yang berbeda namun kemudian di reklasifikasikan kembali sebagai varian MF karena kriteria fenotip yang sesuai dengan MF.

\section{Gejala klinis PR}

Pagetoid reticulosis dapat dijumpai dalam bentuk lesi akral soliter dengan predileksi pada ekstrimitas bawah, terutama pada laki-laki. Lesi berupa bercak/plak berskuama atau verukosa, eritematosa, ukuran besar, soliter, mirip neoplama sel epitel skuamosa dengan pertumbuhan yang lambat.

\section{Gambaran Histopatologik PR}

Secara histopatologik, PR terdiri dari proliferasi limfosit $T$ neoplastik berukuran sedang-besar bersitoplasma luas dan pucat, disertai penebalan stratum spinosum (akantosis) dan penebalan stratum korneum (hiperkeratosis) pada epidemis. Pola pertumbuhan pagetoid dari sel $T$ neoplastik dapat dikaitkan dengan ekspresi kuat molekul adesi, cutaneous lymphocyte antigen (CLA) dan $\mathrm{aE} \beta 7$, yang memfasilitasi interaksi dengan sel endotel dan keratinosit. 
Limfosit $T$ neoplastik dengan epidermotropisme yang prominen membuat PR dapat menyerupai superficial spreading melanoma, karsinoma in situ maupun penyakit Paget. Prognosis PR lebih baik dibandingkan dengan tipe MF lainnya.

\section{Granulomatous Slack Skin (GSS)}

\section{Gejala klinis GSS}

Pada fase awal, GSS mirip dengan gambaran klinis MF klasik yang berjalan menjadi lipatan kulit yang tebal dan menggantung diliputi kulit yang kemerahan atau atropi. ${ }^{3}$

\section{Gambaran Histopatologik GSS}

Granulomatous slack skin memiliki persamaan gambaran histopatologi dengan granulomatous MF, namun gambaran klinis keduanya sangat berbeda. Granulomatous mycosis fungoides (GMF) dan GSS memiliki gambaran umum berupa radang granulomatosa interstisial, tuberculoid, sarkoidal, atau palisading. Radang granulomatosa tersebut dapat mengaburkan gambaran khas MF dan lebih menyerupai penyakit lain seperti granuloma annulare dan atau nekrobiosis lipoidica. Sel raksasa benda asing maupun jenis Touton dengan atau tanpa elastofagositosis fokal juga dapat ditemukan granulomatous slack skin menunjukkan elastolisis/elastofagositosis yang ekstensif dengan keterlibatan subkutan. 2,3

Gambaran klinis varian MF klasik yang lebih jarang berupa bulous MF, dyshidrotic MF, edematous MF, erythema multiforme-like $\mathrm{MF}$, syringotropic MF, palmoplantar MF, hypo/ hyperpigmentation MF, vesicobulous MF, dan unifocal MF. Untuk diagnosis MF dengan varian klinis sangat diperlukan korelasi pemeriksaan histopatologi, imunofenotip dan analisis klonalitas limfosit T.2,9,12,14

\section{Imunofenotip Mycosis Fungoides}

Pemeriksaan proliferasi limfosit $T$ dengan teknik IHK saat ini mulai beralih pada subtipe limfosit T-regulator (T-regs) dan limfosit T-follicular helper (T-FH). ${ }^{16}$ T-regs pada MF mengekspresikan CD4, CD25 dan FoxP3. ${ }^{16}$ Patogenesis MF dipengaruhi oleh lingkungan mikro serta keadaan imun yang dipengaruhi oleh sel dendritik dan limfosit $T$ sitotoksik, sedangkan progresifitasnya dipengaruhi oleh kemampuan limfosit $T$ neoplastik untuk berkembang pada kulit (skin homing ability), yang merupakan hasil dari reaksi kemokin, sitokin, molekul adesi serta apoptosis. ${ }^{2,16}$ Proliferasi limfosit $T$ distimulasi oleh CD28, sedangkan pertumbuhan sel neoplastik, relaps dan remisinya dipengaruhi oleh keberadaan CD30 dengan ligannya CD30L. Transformasi sel besar dengan CD30 yang negatif pada MF memiliki prognosis yang lebih baik untuk reduksi lesi.2,9,10

Mycosis fungoides konvensional dapat mengekspresikan CD3, CD4, CD45RO dan $\beta F 1$, namun kehilangan ekspresi marker limfosit pada umumnya seperti CD2, CD5 dan CD7.7,20 Limfosit $T$ neoplastik dapat mengekspresikan CD4/CD8 dengan rasio lebih dari 10:1 (Gambar 3).

\section{Varian imunofenotip Mycosis Fungoides}

Mycosis fungoides memiliki varian imunofenotip yang tidak khas seperti CD4-/ CD8- (dual negative), CD4-/CD8+ dan CD56+1,19,20 Pada literatur lain disebutkan pula imunofenotip CD4+/CD8+ (dual positive). ${ }^{21}$ Varian MF dengan imunofenotip CD8+ dapat terjadi pada anak-anak dengan hipopigmentasi karena CD8+ sitotoksik akan mempengaruhi pigmentasi kulit. ${ }^{2}$ Gambaran histopatologik varian $\mathrm{CD} 8+\mathrm{MF}$ berupa degenerasi vakuolar yang menonjol, melanin inkontinen dan dapat mengalami underdiagnosis sebagai vitiligo. 

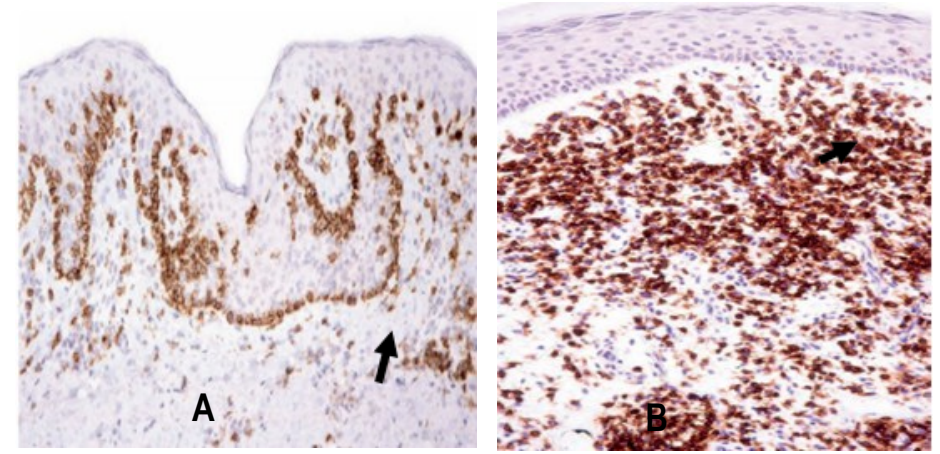

Gambar 3. Imunofenotip MF klasik.

Keterangan : A. Ekspresi CD3 (warna coklat) pada sitoplasma sel T neoplastik di stratum basalis dan dermis superfisial memperjelas gambaran string of pearls dan epidermotropisme (panah hitam); B. Ekspresi CD4 (warna coklat) pada sel T neoplastik di dermis (panah hitam) $(100 \mathrm{x}) \cdot{ }^{9}$

Virmani dkk. (2016) menyebutkan bahwa sejumlah varian lain dari MF yaitu CD30+ terutama pada $40 \%$ MF dengan transformasi sel besar, CD20+ MF, T-follicular helper cell predominant ( $\mathrm{T}$-fh) MF, CD8+ MF, CD4/CD8 double negative MF, TCR gamma+ MF, TIA$1+\mathrm{MF}, \mathrm{CD} 56+\mathrm{MF}$ dan CD45RA+ MF.22

Reaksi granulomatosa pada GMF terjadi akibat dari sekresi faktor kemotaktik oleh sel neoplastik maupun polarisasi untuk memproduksi sitokin Th1, seperti interleukin2 (IL-2), interferon-gamma (IFN- $\gamma$ ) dan tumor necroting factor (TNF-a). Granuloma dapat memacu proliferasi limfosit melalui makrofag yang memproduksi IL-6. ${ }^{8}$

\section{Analisis Klonalitas Mycosis Fungoides}

Neoplasma merupakan populasi yang berasal dari suatu sel prekursor yang dominan (klonal). Berbagai teknik terbaru untuk mendeteksi klonalitas sel neoplasma beberapa tahun terakhir cukup pesat. Pemeriksaan keganasan sel limfoid terdiri dari identifikasi (klonal) rearragement imunoglobulin (IG) dan/atau gen dari $T$-cell receptor (TCR) serta aberasi sejumlah kromosom sebagai marker untuk memeriksa klonalitas. ${ }^{23}$

Pemeriksaan klonalitas dilakukan bila pemeriksaan klinis, histopatologi dan imunofenotip belum cukup kuat untuk menegakkan diagnosis MF. Pengambilan spesimen pada pemeriksaan klonalitas dilakukan pada area yang dicurigai mengandung populasi sel yang monomorfik. ${ }^{23}$ Pencarian rearrangement reseptor antigen untuk analisis klonalitas dan monitoring keberhasilan terapi dapat dilakukan pada semua pasien.

Saat ini telah dikenal teknik biologi molekuler yang dapat mengidentifikasi translokasi kromosom dan rearragement gen reseptor antigen pada lesi limfoproliferasi, yaitu Southern blotting analysis, polymerase reaction chain (PCR) dan next generation sequencing (NGS). Gold standard untuk pemeriksaan klonalitas adalah Southern blotting analysis.

Analisis klonalitas yang menggunakan teknik Southern blotting spesimen harus berupa jaringan segar. Teknik ini berguna untuk mendeteksi rearragement gen berdasarkan perubahan jarak lokasi enzim yang mengalami restriksi pada DNA genomik. Biasanya Southern blotting menggunakan anti-IGH, IGK dan rantai TCR B (TRB) gene rearrangement seperti pada aberasi kromosom lainnya.

Teknik PCR secara bertahap menggantikan prosedur Southern blotting karena lebih cepat dan akurat. PCR dapat mendeteksi fragmen DNA dalam jumlah yang lebih sedikit dan dari sediaan blok parafin. 
Tabel 3. Kriteria diagnosis MF stadium bercak dan plak. ${ }^{15}$

\begin{tabular}{|c|c|}
\hline Kriteria & Scoring \\
\hline \multicolumn{2}{|l|}{ Gejala Klinis } \\
\hline Dasar: & Skor 2: \\
\hline Bercak dan plak yang persisten dan progresif & jika terdapat 1 kriteria dasar $+2 /$ \\
\hline Tambahan: & lebih tambahan \\
\hline 1. Distribusi pada area kulit yang terlindung sinar matahari & Skor 1: \\
\hline $\begin{array}{l}\text { 2. Bentuk dan ukuran lesi yang bervariasi } \\
\text { 3. Poikiloderma }\end{array}$ & $\begin{array}{l}\text { jika terdapat kriteria dasar }+1 \\
\text { tambahan }\end{array}$ \\
\hline \multicolumn{2}{|l|}{ Histopatologik } \\
\hline Dasar : & Skor 2: \\
\hline Infiltrat sel limfoid T pada dermis superfisial & jika terdapat 1 kriteria dasar + 2 \\
\hline Tambahan : & tambahan \\
\hline 1. Epidermotropisme tanpa spongiosis & Skor 1: \\
\hline 2. Sel limfoid berinti atipik & $\begin{array}{l}\text { jika terdapat } 1 \text { kriteria dasar + } 1 \\
\text { tambahan }\end{array}$ \\
\hline \multicolumn{2}{|l|}{ Imunofenotip } \\
\hline $\begin{array}{l}\text { 1. Positif CD2, CD3 dan/atau CD5 pada }<50 \% \text { sel } \mathrm{T} \\
\text { 2. Positif CD7 pada }<10 \% \text { sel T } \\
\text { 3. Kehilangan ekspresi marker sel T pada epidermis }\end{array}$ & $\begin{array}{l}\text { Skor 1: } \\
\text { jika terdapat } 1 \text { atau lebih kriteria } \\
\text { imunofenotip }\end{array}$ \\
\hline Analisis klonalitas & Skor 1 jika terdapat monoklonal \\
\hline
\end{tabular}

Keterangan : Diagnosis MF dapat ditegakkan dengan skor minimal 4

Deteksi perbedaan monoklonalitas dan poliklonalitas PCR didasarkan pada amplifikasi selektif dari IG dan TCR pada regio perbatasan yang tergantung pada ukuran dan komposisi dari amplikon.

Kesulitan evaluasi analisis klonalitas dapat disebabkan: (1). Sensitivitas yang berlebih akibat latar belakang yang poliklonal; (2). Negatif palsu akibat hipermutasi somatik; (3). Positif palsu karena material genetik yang terlalu sedikit; (4). Oligoclonality; (5). Pseudoclonality akibat spesimen terlalu sedikit. ${ }^{22}$

Sekitar $10-15 \%$ dari kasus yang diperiksa analisis klonalitas tersebut tetap meragukan. Dalam hal ini korelasi klinikopatologik sangat penting. ${ }^{20}$ Beberapa dermatosis seperti liken planus, pitiriasis likenoides, liken sklerosis dan purpura pigmentasi maupun infeksi virus tertentu dapat menunjukkan gambaran monoklonal pada pemeriksaan klonalitas. 2,9,23

Data klinis, histopatologi dan imunofenotip diperlukan untuk menjaga objektifitas pemeriksaan analisis klonalitas. Di bawah ini terdapat tabel scoring untuk memudahkan diagnosis MF terutama pada fase dini (Tabel 3). ${ }^{15}$

\section{Kesimpulan}

Dari berbagai literatur tersebut, dapat disimpulkan bahwa aspek klinikopatologi dan imunofenotip merupakan pertimbangan terbaik untuk menegakkan diagnosis MF fase dini. 22

\section{Daftar Pustaka}

1. Kelati $A$, Gallouj $S$, Tahiri L, Harmouche T, Mernissi FZ. Defining the Mimics and Clinico-Histological Diagnosis Criteria for Mycosis Fungoides to Minimize Misdiagnosis. Int J W Dermatol. 2017; 3(2):100106.

2. Song SX, Willemze R, Swerdlow SH, Kinney MC, Said JW. Mycosis Fungoides, Report of the 2011 Society for Hematopathology/European Association for Haematopathology Workshop. Am J Clin Pathol. 2013; 139(4):466-90. 
3. Cerroni L, Sander CA, Smoller BL, Wilemze R. Elder DE, Massi D, Scolyer $\mathrm{RA}$, Willemze $\mathrm{R}$ (Editors). Mycosis fungoides. In : WHO Classification of Skin Tumours. Volume 4. Lyon: IARC Press. 2018. P. 226-33.

4. Litvinov IV, Netchiporouk E, Cordeiro B, Mark- Dore A, Moreau L, Pehr K, et al. The Use of Transcriptional Profilling to Improve Personalized Diagnosis and Management of Cutaneous T-Cell Lymphoma (CTCL). Clin Cancer Res. 2015; 21(12) : 2820-9.

5. Norahmawati E. Fine Needle Aspiration Biopsy has Important Role and High Accuracy as Preoperative Diagnostic Method for Bone Tumors. Jurnal Kedokteran Brawijaya. 2009; 25(2):77-82.

6. Orel SR, Domansky H. Orell SR, Sterrett GF eds. Skin and Subcutis. In : Fine needle aspiration cytology. $5^{\text {th }}$ edition. Elsevier Churchill Livingstone. 2012. P. 370-1.

7. LeBoit PE, Pincus LB. Jaffe ES, Arber DA, Campo E, Harris NL, Martinez-Quintanilla $\mathrm{L}$ (Editors). Mycosis Fungoides and Sezary Syndrome. In : Hematopathology. Elsevier Philadelphia. 2017. P. 713-29.

8. Bagherani N, Smoller BR. An Overview of Cutaneous T Cell Lymphomas. F1000 Research. 2016. DOl:10. 12688/ f1000research. 8829.1.

9. Calonje E, Goodlad J. Calonje E, Brenn T, Lazar A, McKee PH (Editors). Cutaneous Lymphoproliferative Diseases and Related Disorders. In : McKee's Pathology of the Skin with Clinical Correlations. $5^{\text {th }}$ edition. China: Elsevier Saunders. 2020. P. 140530.

10.Wojdylo-MS, Hrab KO, Dziurdzinska KR. Primary Cutaneus Lymphomas: Diagnosis and Treatment. Postep Derm Alergol. 2015; XXXII(5):368-83.

11.Arps DP, Chen S, Fullen DR, Hristov AC. Selected Inflammatory Imitators of Mycosis Fungoides Histologic Features and Utility of Ancillary Studies. Arch Pathol Lab Med. 2014; 138:1319-27.
12.Wilcox RA. Cutaneus T-cell Lymphoma: 2017 Update on Diagnosis, RiskStratification and Management. Am J Hematol. 2017; 92:1085-102.

13.Kumar V, Abbas AK, Aster JC (Editors). Neoplasia. In : Robbins and Cotran : Pathologic Basis of Disease. 9th edition. Elsevier Saunders. 2015. P. 325-30.

14.Kazakov DV1, Burg G, Kempf W. Clinicopathological Spectrum of Mycosis Fungoides. J Eur Acad Dermatol Venereol. 2004; 18(4):397-415.

15.Bagot M, Stadler R. Kang S, Amagai M, Bruckner AL, Eng AH, Margolis DJ, McMichael AJ, Orringer JS (Editors). Cutaneus Lymphoma. In : Fitzpatrick's Dermatology in General Medicine. 9th edition. New york: McGraw-Hill education. 2019; 2072-100.

16.Cerroni L. Past, Present and Future of Cutaneous Lymphomas. Sem D Pathol. 2017; 34:3-14.

17.Wobser M, Geissinger E, Rosenwald A, Goebeler M. Mycosis Fungoides: a Mimicker of Benign Dermatoses. World J Dermatol. 2015; 4(4):135-44.

18.Jawed SI, Myskowski PL, Horwitz S, Moskowitz A, Querfeld C. Primary Cutaneous T -cell Lymphoma (Mycosis Fungoides and Sezary Syndrome): Part 1. Diagnosis: Clinical and Histopathologic Features and New Molecular and Biologic Markers. $J$ Am Acad Dermatol. 2014; 70(2):205.e1-16.

19.Ogunrinade O, Ahn CS, Gergis U, Yassin $\mathrm{AH}$, Magro C. Cutaneus Lymphocyte Antigen Expression Loss and PD1 Positivity in Early Cutaneus Lesions of Rapidly Progressive Mycosis Fungoides. Clinical Case Reports. 2014; 2(5):209-18.

20.Dewar R, Andea AA, Guitart J, Arber DA, Weiss LM. Best Practices in Diagnosis Immunohistochemistry, Workup of Cutaneous Lymphoid Lesions in the Diagnosis of Primary Cutaneous Lymphoma. Arch Pathol Lab Med. 2015; 139(3): 338-50. 
21. Tournier E, Laurent $C$, Thomas $M$, Meyer $N$, Viraben $R$, Brousset $P$, Lamant L. Double -Positive CD4/CD8 Mycosis Fungoides: a Rarely Reported Immunohistochemical Profile. J Cutan Pathol. 2014; 41 (1):58-62.

22. Virmani P, Myskowski PL, Pulitzer M. Unusual Variants of Mycosis Fungoides. Diagn
Histopathol (Oxf). 2016; 22(4):142-51.

23. Gazzola A, Mannu C, Rossi M, Laginestra MA, Sapienza MR, Fuligni $F$, et al. The Evolution of Clonality Testing in the Diagnosis and Monitoring of Haematological Malignancies. The $A d v$ Hematol. 2014; 5(2):35-47. 